\title{
Different Extraction Techniques on the Characteristic Properties of
} Valonea Tannin

\author{
Ersin Onem, Ali Yorgancioglu*, Onur Yilmaz \\ Department of Leather Engineering, Faculty of Engineering, Ege University, Bornova-Izmir, Turkey \\ *ali.yorgancioglu@ege.edu.tr
}

Received: 31 July 2018

Accepted: 07 November 2018

DOI: $10.18466 /$ cbayarfbe.449605

\begin{abstract}
Valonea extract is a natural tannage widely applied in leather industry which is produced via conventional hot water extraction method. On the otherhand more environmental friendly methods have started to be used in extraction technology recently. Present paper reports on the effect of different extraction methods on the properties of valonea extracts. For this purpose, conventional solvent extraction (CSE) (methanol/water mixture), supercritical $\mathrm{CO}_{2}\left(\mathrm{scCO}_{2}\right)$ extraction and pressurized fluid extraction (PFE) (water/ $\mathrm{CO}_{2}$ binary system) techniques have been employed on valonea and the obtained extracts have been characterized. Molecular weight of the tannins was determined by gel permeation chromatography (GPC), particle size was examined by Malvern Zetasizer instrument, chemical structure by Fourier Transform Infrared Spectroscopy (FTIR). Tannin content was also examined and the results were compared with commercial valonea extract (CVT). The results showed that especially particle size of the tannins was affected by the applied extraction method and the smallest particle size was obtained by PFE method as $505.3 \mathrm{~nm}$ compared to commercial tannin as $983.0 \mathrm{~nm}$ of average particle size. PFE method was also provided more uniform extract according to the polydispersity index values. GPC and FTIR analyses showed slightly differences on the characteristics of tannins.
\end{abstract}

Keywords: Leather, valonea tannin, conventional solvent extraction, supercritical $\mathrm{CO}_{2}$ extraction, pressurized fluid extraction, characterization.

\section{Introduction}

During tanning step, several tanning agents are applied. Selection of these materials in tanning application varies on the desired leather goods such as garment, upholstery, shoe upper etc. Nevertheless, $80-90 \%$ of the global leather production is carried out with chromium (III) salts [1]. However, leather sector is recently searching for the alternative tannage options based on the natural products as vegetable tanning agents [2]. Vegetable tannins can be used with different tanning agents to get the required leather properties. In Europe, vegetable tannages are widely prefered for high-priced luxury leather goods. These herbal extracts are generally manufactured by conventional hot water extraction method of selected plant parts which rich in polyphenolic substituents. The content of tannins, nontannins and their characteristic properties are the major criterion for assessment of the extracts. In the tanning process, tannin extracts penetrate into the hide/skin and crosslink with the active groups of collagen. This linkage provides a stabilization of the collagen leading to increased hydrothermal stability and good resistance against microorganisms. The higher quality of an extract brings the higher efficacy in tanning process [3].

Tannins are secondary complexes and widely distributed in the plants. Tannins are categorized with two major groups as ester derived hydrolysable and flavanoid derived condensed tannins [4]. Tannins obtained from oak tree growing in the Mediterranean region are defined as valonea. Valonea among the hydrolysable tannins are mostly used in leather production for tannage and retannage steps either alone or in combination with other tannins [5]. Chemical structures of active hydrolysable tannin consitutents of valonea are ellagic acid, gallic acid, geraniin and corilagin are as given in Figure 1 [6]. 


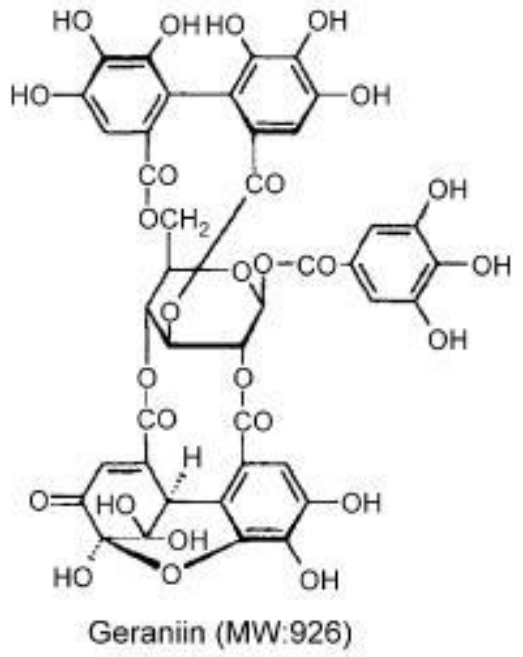<smiles>O=c1oc2c(O)c(O)cc3c(=O)oc4c(O)c(O)cc1c4c23</smiles>

Ellagic Acid (MW:338)

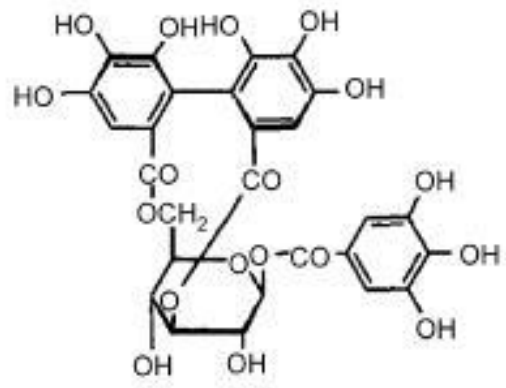

Corilagin (MW:635)<smiles>O=C(O)c1cc(O)c(O)c(O)c1</smiles>

Gallic Acid (MW:170)

Figure 1. Basic structures and their molecular weights of valonea tannin.

The matured acorn cups are picked up in certain season between October and March. They are dried and dispatched to the extraction facilities. Tannins are generally extracted with empirical ways in hot water to leach the tannin compounds [7]. Employed extraction methods affect the structure of the complex, content of tanning phenolic compounds, molecular weight, particle size and other general properties of tannins [8-10]. Therefore, different extraction ways are developed for the well isolation of the phenolic compounds from natural matrix [11]. There is a rising demand to improve the proper techniques to get the high quality of tannins $[12,13]$.

Valonea tannin gives excellent firmness, good lightfast, fullness and lower water absorption properties for leather compared to the other natural tannages. On the other hand, the application of valonea during the tanning process causes high astringency of tanning, sludge formation in the process pits and unfavorable color for leather products [14]. These properties are also responded by the applied isolation methods [15].

This study aims to investigate the effect of different extraction tecniques such as conventional solvent extraction (CSE) (methanol/water mixture), supercritical $\mathrm{CO}_{2}\left(\mathrm{scCO}_{2}\right)$ extraction and pressurized fluid extraction (PFE) (water/ $\mathrm{CO}_{2}$ binary system) on the characteristic properties of valonea tannin. Characteristic properties of $\mathrm{CSE}, \mathrm{scCO}_{2}$ and $\mathrm{PFE}$ extracted valonea tannins were also compared with commercial valonea extract.

\section{Materials and Methods \\ 2.1. Materials}

Turkish oak acorns were used for the extraction processes. They were obtained from "Balaban Izmir Palamut Ltd. Company" in Manisa, Turkey. Lowchromed $\left(\mathrm{Cr}_{2} \mathrm{O}_{3}\right.$ content $\left.<0.8 \%\right)$ hide powder was purchased from FILK (Research Institute of Leather and Plastic Sheeting, Freiberg, Germany) and used for the phenolic content analyses.

\subsection{Methods}

\subsubsection{Extraction of the valonea tannin with different} techniques

CSE extraction of valonea tannin was realized under the

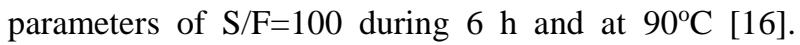
Supercritical $\mathrm{CO}_{2}$ extraction was carried out at $70^{\circ} \mathrm{C}$ under 70 bar during $60 \mathrm{~min}$. (20\% co-solvent: methanol). Water/ $\mathrm{CO}_{2}$ binary pressurized fluid system was applied with the parameters of $\mathrm{S} / \mathrm{F}=100$ with 100 bar during $3 \mathrm{~h}$ and at $80^{\circ} \mathrm{C}$ [17].

\subsubsection{Tannin content analysis (hide-powder method)}

The tanning phenolic contents of the produced extracts and the commercial valonea sample were analysed according to the official standards of SLC 114, 115, 116 and 117 . 


\subsubsection{Molecular weight determination of valonea extracts}

Aqueous Malvern Gel Permeation Chromatography (GPC) was used for determination of average molecular weights and polydispersity indexes of the produced valonea tannins. $0.1 \mathrm{M} \mathrm{NaNO}_{3}$ and $0.5 \% \mathrm{NaN}_{3}$ aqueous solution were used as the mobile phase with a flow rate of $0.7 \mathrm{~mL} / \mathrm{min}$ during the measurements. Before the analyses, the valonea tannins in $5 \mathrm{mg} / \mathrm{mL}$ concentration were dissolved in GPC eluent and shaken for at least 6 hours to obtain a complete dissolution. Then, the valonea samples were filtered by $0.45 \mu \mathrm{m}$ injector filters and measured for the determination of number average molecular weights $(\mathrm{Mn})$, weight average molecular weight $(\mathrm{Mw})$, molecular weight distributions and polydispersity index (PDI).

\subsubsection{Particle size analysis}

Particle size distribution of the tannins was carried out with a Malvern Zetasizer Nano ZS 90 particle size analyzer (Malvern Inst. Ltd., UK) under room temperature. For the analysis, tannin samples were prepared as $0.1 \mathrm{mg} / \mathrm{mL}$ concentration by diluting with the ultrapure water. The measurement size range of the instrument was 0.1-10000 $\mathrm{nm}$.

\subsubsection{Fourier transform infrared spectroscopy characterization}

The structural analysis of valonea tannin samples was performed by using Perkin Elmer FT-IR+ATR spectrometer (Spectrum-100 model). The IR spectra of the samples in powder form were provided after 5 scans between 4000-650 $\mathrm{cm}^{-1}$ using $2 \mathrm{~cm}^{-1}$ discriminating power.

\section{Results and Discussion}

Tanning phenolic contents of valonea tannins produced in different extraction conditions for the CSE, PFE and $\mathrm{scCO}_{2}$ were given in Table 1 by comparing the CVT sample.

Table 1. Tanning phenolic contents related to extraction method.

\begin{tabular}{|c|c|}
\hline Extracts & $\begin{array}{c}\text { Tanning phenolic } \\
\text { contents }(\%)\end{array}$ \\
\hline CVT & 58.34 \\
\hline PFE & 63.90 \\
\hline $\mathrm{CSE}$ & 62.03 \\
\hline $\mathrm{ScCO}_{2}$ & 59.20 \\
\hline
\end{tabular}

In conventional extraction processes, it is tried to dissolve the components of the plant by long treatment time. However, phenolic compounds that are not tannins are also taken into consideration at the long extraction process, the extraction yield (\%) seems to be higher but the content of tannin (\%) of the extract is decreased. For this reason, it is necessary to give more extract to the drum in order to get enough tannin content on the leather weight during the production. It means that the content of tannin is more important than the extraction efficiency. However, high tannin content (\%) from acorn cups was obtained with $\mathrm{ScCO}_{2}$ and PFE extractions in short application time. This situation will be quite advantageous for reducing the cost of extracts and the waste load occured in tanning and retanning steps in the factories where tons of leather produced.

Another methods are tried to increase the extraction efficiency, as well. Chestnut tannin is also widely applied in vegetable tanning process in leather sector. Vázquez et al. reported the extraction yield of chestnut shell as $8.7 \%$ at $70^{\circ} \mathrm{C}$ and $12.2 \%$ at $90^{\circ} \mathrm{C}$ in water [8]. $10 \% \mathrm{NaOH}$ and water solvent mixture was used to increase the extractability of tannin compounds. $49.4 \%$ extract yield was obtained at $70^{\circ} \mathrm{C}$, but $\mathrm{pH}$ value oft he extract was 9.3 which is a significant drawback for the industrial applications. Because lower $\mathrm{pH}$ values are required for vegetable tanning process for the good penetration of tannin compounds to leather matrix. Moreover, molecular weight of the extract decreased with the $\mathrm{NaOH}$ application.

The particle size and chemical composition of the chemicals used in the leather production is one of the most important factor both affecting the performance and the properties of leather. While the small particle size of the chemicals is capable of a high penetration rate into leather, the larger the particle size the chemicals have a low penetration rate. Sivakumar et al. have also reported that particle size of the tannins are highly considerable factor for the vegetable tanning process of leather [20]. Results of the particle size analyses of valonea tannins obtained from extraction methods applied are given in Table 2.

Table 2. Results of the particle size analyses of valonea tannins.

\begin{tabular}{|l|c|c|}
\hline Samples & $\begin{array}{c}\text { Average particle } \\
\text { size (nm) }\end{array}$ & $\begin{array}{c}\text { Polydispersity } \\
\text { index }\end{array}$ \\
\hline CVT & 983.0 & 0.559 \\
\hline PFE & 505.3 & 0.512 \\
\hline $\mathrm{CSE}$ & 711.1 & 0.719 \\
\hline $\mathrm{ScCO}_{2}$ & 877.8 & 0.880 \\
\hline
\end{tabular}



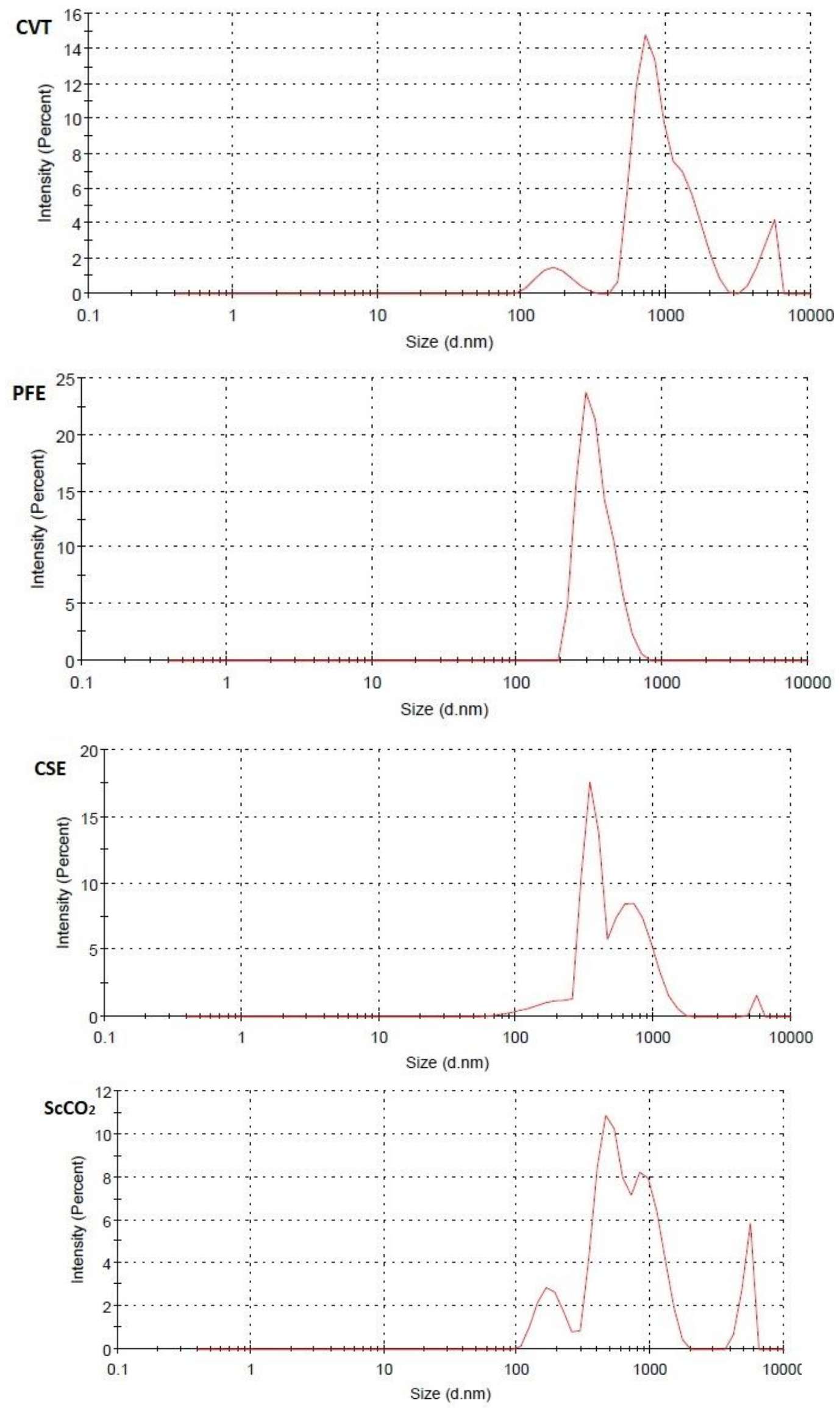

Figure 2. Particle size distribution of valonea tannins. 
It was monitored that the average particle size decreased from $983.0 \mathrm{~nm}$ to $505.3 \mathrm{~nm}$ with the pressurized fluid extraction method (water/ $\mathrm{CO}_{2}$ binary system) compared to commercial valonea tannin (CVT) produced by water extraction. Thermodynamically, the density of $\mathrm{CO}_{2}$ increases with the increased pressure at a constant temperature. This resulted in decreased particle size formation $[18,19]$. The polydispersity index (PDI) is related with the size distribution/uniformity of the particles. Thus, higher polydispersity index brings poor uniformity in particle size distribution [20]. The best uniformity was also provided by pressurized fluid extraction method (water/ $\mathrm{CO}_{2}$ binary system) with low PDI value as seen in Table 2.

Sivakumar et al. revealed that particle size of the tannins was decreased by ultrasonic extraction application, penetration ability of the tannins were affected and improved [17]. Thus, float exhaustion was also increased in the production by tannins. The extracts obtained by pressurized methods can be used to improve the float uptake in tanning processes, reduce the environmental pollution and decrease the process time. Teng et al. used different particle sized tannins obtained from Acacia mangium bark and reported that the penetration time of tannin was the longest, with up to 96 $\mathrm{h}$ required for its biggest particle size [9]. Conversely, extracted tannin with the smallest particle size penetrated quickly, and only $36 \mathrm{~h}$ was required for complete penetration.

The effect of extraction methods on the molecular weight of tannins were also investigated using gel permeation chromatography. The results are given in Table 3 and Figure 3.
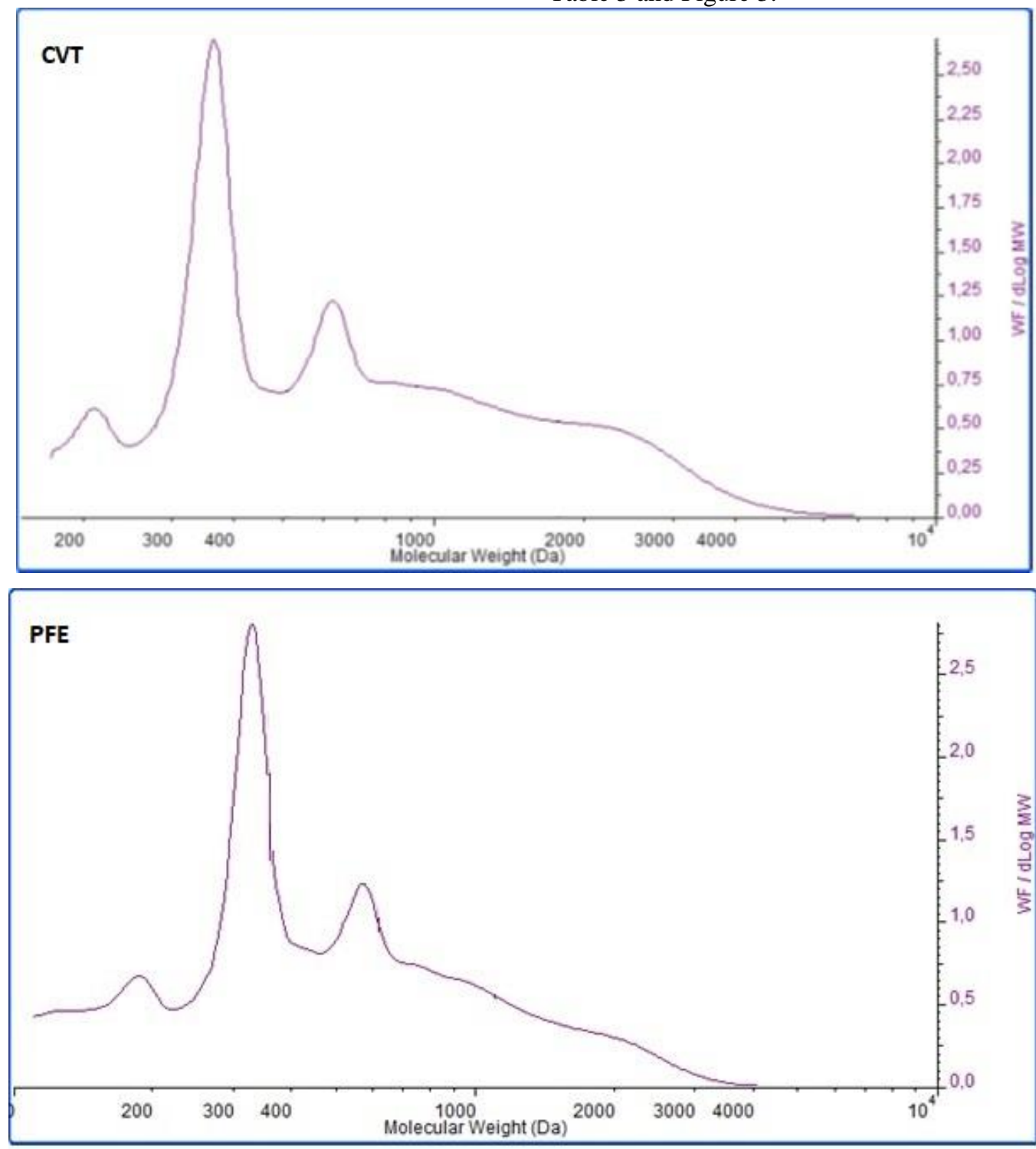

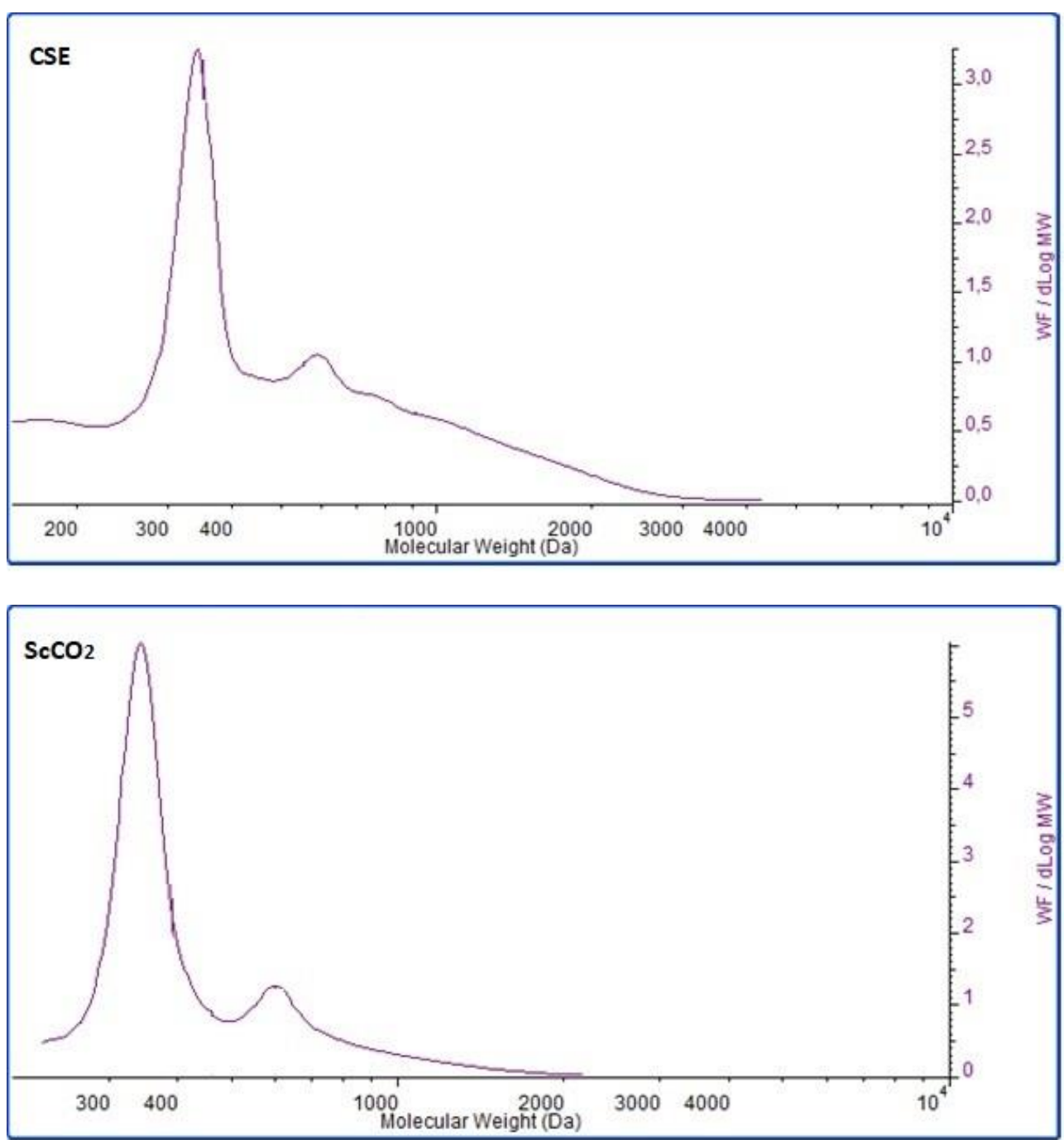

Figure 3. GPC spectra of valonea extracts.

The results indicated that the molecular weight distribution of the samples were in the range of 150$7000 \mathrm{Da}$ with different molecular fractions. Similar results were also obtained for valonea tannin in a study by Ozgunay et al. where the molecular weights were investigated by MALDI-TOF technique [13]. The samples of CVT and PFE had 3 main distribution peaks while samples $\mathrm{CSE}$ and $\mathrm{scCO}_{2}$ had two peaks possibly due to the different fractions of molecular species. The major peak of species were observed at 331-366 Da and second major peak at 572-632 Da. The most broad distribution with slightly higher molecular weights were observed at CVT where the other extraction methods used in the study resulted in lower molecular weight distribution. The most narrow molecular weight distribution was observed at $\mathrm{scCO}_{2}$ extracted valonea tannins being in the range of 225-2000 Da. These results show that the extraction methods rather than conventional one have also effect on molecular weight of the valonea tannin since they give lower molecular weight species.

Table 3. Effect of extraction methods on the molecular weight of tannins.

\begin{tabular}{|l|c|c|c|c|}
\hline Extracts & $\begin{array}{c}\mathbf{M}_{\mathbf{w}} \text { Distribution } \\
\text { range (Da) }\end{array}$ & $\mathbf{M}_{\mathbf{p} 1}$ (Da) & $\mathbf{M}_{\mathbf{p} 2}$ (Da) & $\mathbf{M}_{\mathbf{p} 3}$ (Da) \\
\hline CVT & $150-7000$ & 210 & 366 & 532 \\
\hline PFE & $140-4000$ & 187 & 331 & 572 \\
\hline CSE & $220-4000$ & 136 & 347 & 605 \\
\hline ScCO2 & $225-2000$ & - & 345 & \\
\hline
\end{tabular}


The chemical characterization of the valonea extracts was done by FTIR and their spectra are given in Figure 4. From the results it was observed that all the valonea extracts had very similar spectrum and the main characteristic absorption bands appeared at $3276 \mathrm{~cm}^{-1}$ for $-\mathrm{OH}$ strecthing, $2920 \mathrm{~cm}^{-1}$ for $-\mathrm{CH}$ stretching, 1720 $\mathrm{cm}^{-1}$ for $\mathrm{C}=\mathrm{O}, 1610$ and $1447 \mathrm{~cm}^{-1}$ for $\mathrm{C}=\mathrm{C}$ of aromatic rings, $1315 \mathrm{~cm}^{-1} \mathrm{C}-\mathrm{OH}$ (in plane), $1179 \mathrm{~cm}^{-1}$ for $\mathrm{C}-\mathrm{O}-\mathrm{C}$ ester bonds and $1038 \mathrm{~cm}^{-1}$ for $\mathrm{C}-\mathrm{O}$ of $\mathrm{C}-\mathrm{OH}$ groups. On the other hand an intensity difference of the peaks at 1720 and $1610 \mathrm{~cm}^{-1}$ was observed especially for the sample $\mathrm{ScCO}_{2}$ which showed that the content of molecular species carrying $-\mathrm{C}=\mathrm{O}$ was higher. This may be due to the partial carboxylation of some phenolic rings during supercritical $\mathrm{CO}_{2}$ extraction. However, all the spectra showed that characteristic peaks of valonea tannin as reported also by other researchers [13].

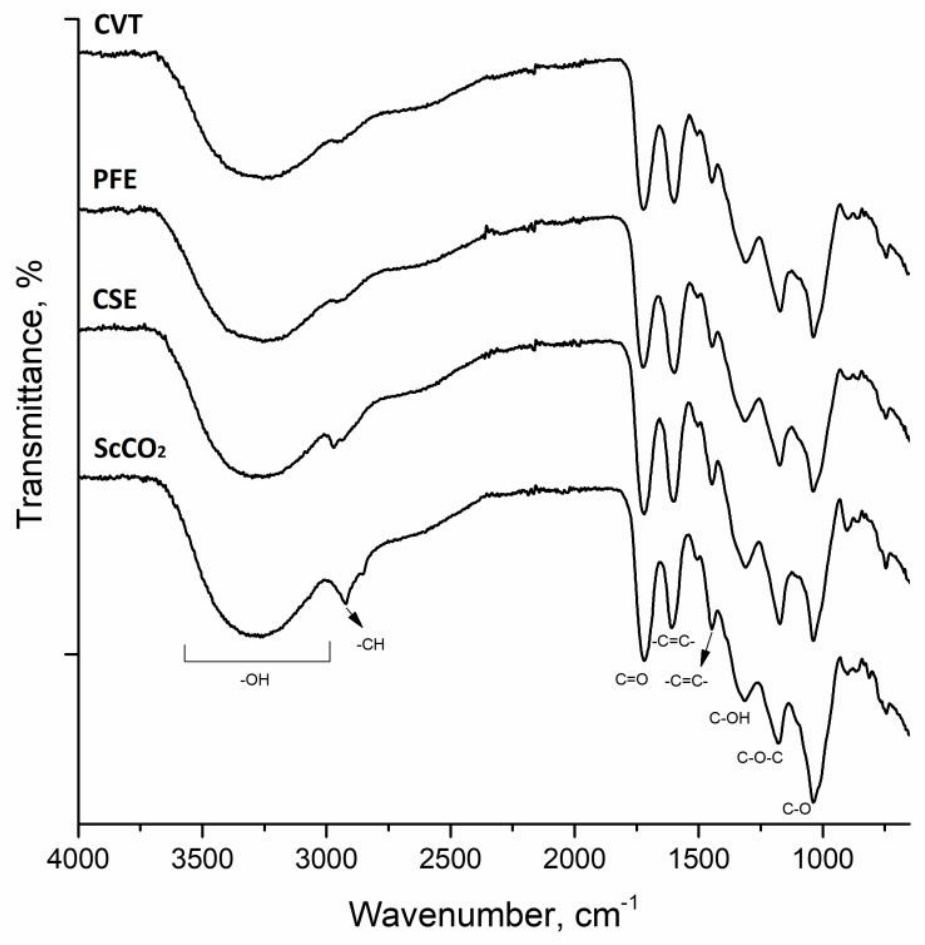

Figure 4. FTIR spectra of tannins.

\section{Conclusion}

Different extraction techniques were employed on valonea tannin their characteristics were investigated. The overall results exhibited that many important properties of valonea tannin have been affected by the applied extraction techniques such as particle size, molecular weight and chemical structure of the extracts which can have further affect their tanning properties. From this point of view, it has been clearly appeared that proper extraction methods should be determined according to the desired features of the tannins. This situation is importance for the leather goods to be produced because it may have effect on their quality and performance parameters. PFE method contributes to the extraction efficiency and does not adversely affect the characteristic and quality properties of the tannins which are considerable in terms of the leather production. Moreover, the methods provide more uniform and smaller particle size as well as relatively lower molecular weight extracts can be advantageous during tanning and retanning applications. Applied extraction method should not be ignored in terms of the environmental aspects and sustainable production as well. For these reasons, supercritical fluid and pressurized fluid application techniques have gained much importance by the industry as they offer more ecofriendly and efficient extraction.

\section{References}

1. Renner, M, Weidner, E, Björn, J, Helmut, G, Free of water tanning using $\mathrm{CO}_{2}$ as process additive - an overview on the process development, Journal of Supercritical Fluids, 2012, 66, 291-296.

2. Sundar, V.J, Muralidharan, C, Mandal, A.B, Eco-benign stabilization of skinprotein - role of Jatropha curcas oil as a cotanning agent, Industrial Crops and Products, 2013, 47, 227-231.

3. Maier, M, Oelbermann, A.L, Renner, M, Weidner, E, Screening of European medicinal herbs on their tannin content-New 
potential tanning agents for the leather industry, Industrial Crops and Products, 2017, 99, 19-26.

4. Kanth, S.V, Venba, R, Madhan, B, Chandrababu, N.K, Sadulla, S, Cleaner tanning practices for tannery pollution abatement: Role of enzymes in eco-friendly vegetable tanning, Journal of Cleaner Production, 2009, 17, 507-515.

5. Huang, W, Niu, H, Li, Z, Li, L, Wang, W, Ellagic acid from acorn fringe by enzymatic hydrolysis and combined effects of operational variables and enzymes on yield of the production, Bioresource Technology, 2008, 99, 1518-1525.

6. Markom, M, Hasan, M, Wan Daud, W.R, Singh, H, Jahim, J.M Extraction of hydrolysable tannins from Phyllanthus niruri Linn.: Effects of solvents and extraction methods, Separation and Purification Technology, 2007, 52, 487-496.

7. Timur, S, Kantarli, I.C, Onen, S, Yanik, J, Characterization and application of activated carbon produced from oak cups pulp Journal of Analytical and Applied Pyrolysis, 2010, 89, 129-136.

8. Vázquez, G, González-Alvarez, J, Santos, J, Freire, M.S Antorrena, G, Evaluation of potential applications for chestnut (Castanea sativa) shell and eucalyptus (Eucalyptus globulus) bark extracts, Industrial Crops and Products, 2009, 29, 364-370.

9. Teng, B, Zhang, T, Gong, Y, Chen, W, Molecular weights and tanning properties of tannin fractions from the Acacia mangium bark, African Journal of Agricultural Research, 2013, 8, 59966001

10. Yildiz, E, Karabulut, D, Celiktas, O.Y, A bioactivity based comparison of Echinacea purpurea extracts obtained by various processes, Journal of Supercritical Fluids, 2014, 89, 8-15.

11. Rangsriwong, P, Rangkadilok, N, Satayavivad, J, Goto, M, Shotipruk, A, Subcritical water extraction of polyphenolic compounds from Terminalia chebula Retz. fruits, Separation and Purification Technology, 2009, 66, 51-56.

12. Zhao, S, Zhang, D, A parametric study of supercritical carbon dioxide extraction of oil from Moringa oleifera seeds using a response surface methodology, Separation and Purification Technology, 2013, 113, 9-17.

13. Ozgunay, H, Sari, O, Tozan, M, Molecular investigation of valonea tannin, Journal of the American Leather Chemists Association, 2007, 102, 154-157.

14. Yang, L, Wang, D, Zhou, D, Zhang, Y, Effect of different isolation methods on structure and properties oflignin from valonea of Quercus variabilis, International Journal of Biological Macromolecules, 2016, 85, 417-424.

15. Onem, E, Gulumser, G, Akay, S, Celiktas, O.Y, Optimization of tannin isolation from acorn and application in leather processing, Industrial Crops and Products, 2014, 53, 16-22.

16. Onem, E, Gulumser, G, Renner, M, Oelbermann, A.L, Celiktas, O.Y, Pressurized fluid extraction (PFE) of valonea tannin with binary $\mathrm{H}_{2} \mathrm{O}-\mathrm{CO}_{2}$ and ternary $\mathrm{H}_{2} \mathrm{O}-\mathrm{CH}_{3} \mathrm{OH}-\mathrm{CO}_{2}$ systems and phase equilibrium studies, Separation and Purification Technology, 2015, 146, 101-107.

17. Sivakumar, V, Swaminathan, G, Rao, P.G, Ramasami, T, Sonoleather technology with ultrasound: A boon for unit operations in leather processing - review of our research work at Central Leather Research Institute (CLRI), India, Ultrasonics Sonochemistry, 2009, 16, 116-119.

18. Kalani, M, Yunus, R, Abdullah, N, Optimizing supercritical antisolvent process parameters to minimize the particle size of paracetamol nanoencapsulated in L-polylactide, International Journal of Nanomedicine, 2011, 6, 1101-1105.

19. Celiktas, O.Y, Uyanikgil, E.O.C, In vitro release kinetics of polycaprolactone encapsulated plant extract fabricated by supercritical antisolvent process and solvent evaporation method, Journal of Supercritical Fluids, 2012, 62, 219-225.

20. Natarajan, V, Krithica, N, Madhan, B, Sehgal, P.K, Formulation and evaluation of quercetin polycaprolactone microspheres for the treatment of rheumatoid arthritis, Journal of Pharmaceutical Sciences, 2011, 100, 195-205. 